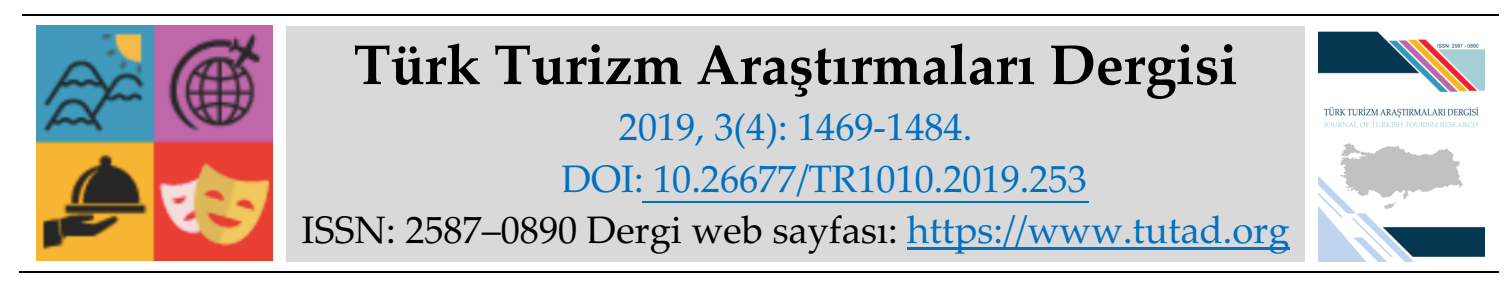

ARASTIRMA MAKALESI

\title{
Beş Duyu, Tat Alma Duyusu ve Lezzetin Alegorisi
}

Dr. Öğr. Üyesi Defne AKDENIZ, Çanakkale Onsekiz Mart Üniversitesi, Ayvacık Meslek Yüksekokulu, Çanakkale, e-posta: defneakdeniz@comu.edu.tr ORCID: https://orcid.org/0000-0001-8572-5438

$\ddot{O} z$

Aristoteles'in beş duyuya dair ileri sürdüğü kuram Avrupa'da tıp bilimlerinin yanı sıra güzel sanatlar, edebiyat ve felsefe alanında pek çok düşünürün ilgisini çekmişti. Beş duyunun yeniden yorumlanması resim sanatında da oldukça rağbet görmüştü. Resim sanatı, dünyevi gerçeklikler hakkında bilgi toplayan duyuların işleyişini genellikle somut gerçekliklerin ötesindeki ilahi dünyayı çağrıştırmada kullanıyordu. Bu yaklaşım ışığında beş duyunun resim sanatındaki yansımaları kutsal kitaplardan besleniyordu. Yeme eyleminin izini süren bu çalışma, beş duyu ve özellikle tat alma duyusunun resim sanatındaki temsillerini incelemektedir. Araştırmasını yaparken dinden, tarihten, mitolojiden ve ikonografiden yararlanmakta ve resimde görülen yüzeysel gerçekliklerin arkasındaki metaforik anlamları açığa çıkarmaktadır. Ele aldığı resim sanatı örnekleri, tat alma duyusunun insanların hayvanlarla ortak sahip olduğu ilkel bir duyu olduğu ve bu duyunun kötü kullanımının insanı şehvete ve günaha sürükleyeceğini ortaya koymaktadır. İncelenen resim sanatı örneklerinde ilgi çeken bir diğer nokta ise yeme günahının genellikle kadın öğesi ile temsil edilmiş olmasıdır.

Anahtar Kelimeler: Yeme Eylemi, Tat Alma Duyusu, Gastronomi, Resim Sanat1, Sembolizm.

Makale Gönderme Tarihi: 14.06.2019

Makale Kabul Tarihi: 05.10.2019

\section{Önerilen Atıf:}

Akdeniz, D. (2019). Beş Duyu, Tat Alma Duyusu ve Lezzetin Alegorisi, Türk Turizm Araştırmaları Dergisi, 3(4): 1469-1484.

(C) 2019 Türk Turizm Araştırmaları Dergisi. 


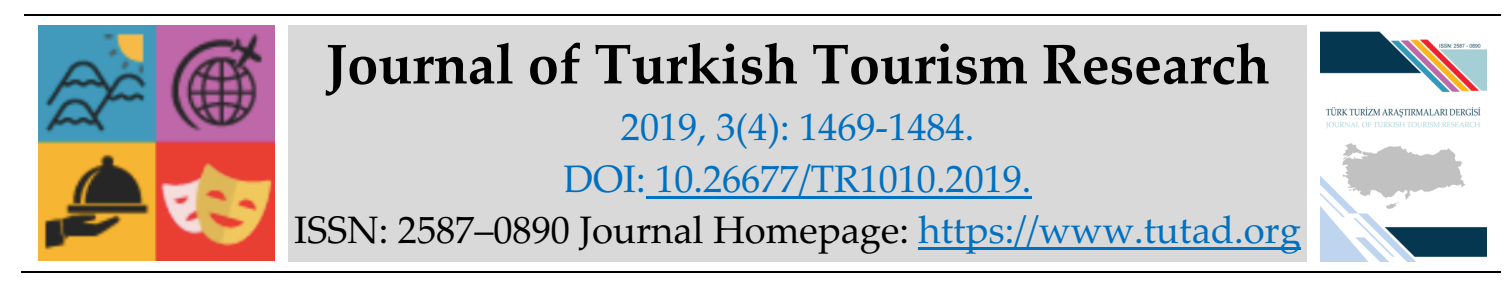

\title{
$\underline{\text { RESEARCH PAPER }}$
}

Five Senses, Sense of Taste and Allegory of Taste

Assistant Prof. Dr. Defne AKDENIZ, Çanakkale Onsekiz Mart University, Ayvacık Vocational School, Çanakkale, e-mail: defneakdeniz@comu.edu.tr

ORCID: https://orcid.org/0000-0001-8572-5438

\begin{abstract}
Aristotle's theory of five senses attracted the attention of many thinkers in the field of fine arts, literature and philosophy, as well as medical sciences in Europe. The art of painting often interpreted senses as instruments to gather information about earthly realities and to understand the divine world through concrete realities. Within this approach, the representations of the five senses in the art of painting were generally referred to holy books. This study, which aims to acquire more understanding about eating and taste, examines the representations of five senses and especially the sense of taste in the art of painting. While doing this, the researcher advances religion, history, mythology and iconography and reveals the symbolic meanings hidden behind the surface. One of the findings of the study reveal that the sense of taste is a primitive sense that humans have in common with animals, and that the misuse of this sense will lead to lust and sin. Another finding is that the act of eating and leading into temptation is usually represented by female figures in the painting.
\end{abstract}

Keywords: The Act of Eating, Sense of Taste, Gastronomy, Art of Painting, Symbolism.

Received: 14.06 .2019

Accepted: 05.10.2019

\section{Suggested Citation:}

Akdeniz, D. (2019). Five Senses, Sense of Taste and Allegory of Taste, Journal of Turkish Tourism Research, 3(4): 1469-1484.

(C) 2019 Türk Turizm Araştırmaları Dergisi. 


\section{Gíriş}

İnsana ve yaşama dair olanın gözlemlenmeye başlandığı dönemlerde insanın çevresini gözlemleyip yorumlamada kullandığı beş duyu organı (görme, işitme, koklama, tat alma ve dokunma), hümanistik ve felsefi düşüncede yaygın ilgi görmüştür. Özellikle Aydınlanma Çağı'nda Aristoteles gibi antik çağ düşünürleri tarafından ruh ve beden üzerine geliştirilen kuramların tekrar ele alınmasıyla birlikte beş duyu üzerine yapılan çalışmalar artmaya başlamıştır. Beş duyunun konu edildiği metinler ve resimlerde (gravür, tablo vb.) duyular salt çevreyi duyumlamaya yarayan fiziksel gereçler olmanın ötesinde farklı bir tartışma boyutuna taşınmıştır. Duyular ve duyu organlarının imgelendiği görsel betimlemelere, dönemin toplumsal, kültürel yapısına ve dini inanışına paralel olarak, farklı kodlar ve anlamlar atanmıştır. Duyular kutsal kitap meselleri ışığında yorumlanmış ve toplumun yozlaşmasına neden olan haz merkezleri olarak ele alınmıştır. Özellikle Ortaçağ'da Kilise ve din adamları tarafından bedensel hazların farkına varılmasını sağlayan fiziksel gereçler olarak ahlaksızlığın, şehvet düşkünlüğünün ve günahkârlığın ikonu olarak kullanılmışlardır. Duyu organlarının algıladığı geçicilik ve faniliğin karşısına hiçbir zaman yok olmayan ilahi dünya konmuştur. Zıtlıklar aracılığıyla yapılan bu alegorik anlatım sayesinde duyuların gösterdiği yüzeysel ve nesnel gerçekliklere yeni anlamlandırmalar ve eklemeler yapılmıştır.

Beş duyunun, tat alma duyusunun ve lezzetin alegorisinin temsili üzerine yapılan bu araştırmanın amacı Ortaçağ ve sonrasında özellikle 16. ve 17. yüzyıllarda resim sanatında görülen beş duyu ve tat alma duyusu temalı yapıtları belirlemek, tat alma duyusunun ve lezzetin etrafında şekillenen ahlaki yapıyı, teamülleri ve ikonografiyi incelemektir. Çalışma sanat eserlerinde yüzeyde yer alan beş duyu temasının ressamlarca neden ele alınmış olduğunu ve eserlerde yer alan imgelerin neleri temsil ettiklerini irdelemektedir. İncelemesini yaparken dönemin özelliklerini, toplumsal ve ekonomik yapıyı, dini doktrinleri ve ahlaki örüntüleri dikkate alan çalışma, tat alma duyusuna atfedilen örtük anlamları ve kodlamaları sorgulamaktadır. Eserlerde görülen 'beş duyu ve/ya tat alma duyusunun' salt duyu organlarınca bedene transfer edilen duyumlar olmadığını, duyuların ve lezzetin çoğu kez bir olgunun, bir öğretinin ya da bir uyarının imgelemi olduğunu ortaya koymaktadır.

Araştırmasına beş özel duyu üzerine yapılan felsefi görüşlerden başlayan bu çalışma, öncelikle Aristoteles'in beden ve ruh kuramına değinmektedir. Aristoteles'in ruhun işlevlerinden biri olan duyumu gerçekleştiren duyu organlarına yaklaşımını inceledikten sonra, beş duyunun resim sanatına neden ve nasıl girdiğine odaklanmaktadır. Ortaçağ Avrupa'sında ve sonrasında beş duyunun görsel yollarla betimlenme ve yorumlanma biçimlerini dönemin kültürel, dini, toplumsal, ekonomik atmosferi ışı̆̆ında irdelemektedir. Daha sonra yönünü tat alma duyusuna çeviren çalışma, resim sanatında görülen yemek yeme, tat alma ve lezzet olgularının hangi anlamların göstergesi olduğuna odaklanacaktır. Dönemin sanat ve kültür politikasına dair gerekli bilgilerin verilmesinin ardından beş duyu resimlerinin bir parçası olan 'Tat Alma Duyusu' temalı yapıtlarda yer alan nesneler ve figürler açıklanmaktadır. Tat alma duyusunun tüm kutsal kitaplarda yer alan ilk günah meselinin ikonografik anlatımında yaygın kullanıldığını tespit eden bu çalışma, tat alma duyusu merkezinde gelişen feminen örüntüye, beyhudelik ve geçicilik inancına, gizil veya açı ahlaki mesajlara ve bir dönemin toplumsal pratiklerine ışık tutmaktadır. Tat alma duyusunun sadece yemek yeme eylemiyle ilintili bir işlevi olmadığını, fiziksel işlevinin ötesinde yeni bir lisanla farklı içerikleri nasıl yansıttığını incelemektedir. Bu çalışma, tat alma duyusunun yalnızca dışsal ve nesnel bir gerçeklikten ibaret olarak okunamayacağını ve olgunun dolaylı ve sembolik bir yapı içinde açıklanması gerektiğini ortaya koyması açısından önem taşımaktadır. 


\section{LİTERATÜR}

Beş duyu ve tat alma duyusu üzerine oluşturulan literatür Antik Çağ’lara kadar uzanır. Antik Çağ filozofları, algılama, ruh ve beden üzerine yaptıkları varsayımlarda algı merkezlerini devreye sokmuşlardır. Başlangıçta yalnızca 'görme' üzerinden yapılan algı tartışmalarına Aristoteles koklama, dokunma, tat alma ve işitme duyularını da eklemiştir (Nordenfalk, 1985). Modern bilim dünyası duyu sayısını bugün 33'e kadar çıkarmışsa da insanlık yüzyıllar boyunca dış dünyanın beş duyuyla algılandığını benimsemiştir (http://www.hurriyet.com.tr).

Aristoteles ruh ve beden üzerine oluşturduğu kuramda ruhu, bitkisel, hayvansal ve insani ruh olmak üzere üç hiyerarşik gruba ayırmıştır. Bitkisel ruh, ruhu besleyen yani bitkisel hayatı sağlayan ilk ve en genel derecedir. Bu ruh tüm canlılarda bulunur, onlara hayat verir. Bu ruh canlılarda büyüme, üreme, başkalaşma gibi çeşitli fiziksel değişiklikler meydana getirmektedir. Hayvani ruh ise hareket ve duyarlılı̆ga sahiptir. Hayvanlarda ve insanlarda bulunur. Bitkisel ruhun sahip olduğu niteliklere ek olarak canlının hareket etme, arzu duyma ve duyumsama faaliyetlerini yerine getirir. İnsani ruhun özelliği ise diğer ruhlara aklı eklemesidir. Aristoteles, insanı diğer canlılardan farklı kılan şeyin insani ruh olduğunu söyler. Hayvanlar kendilerinde bulunan bitkisel ve hayvansal ruh sayesinde beslenme, duyumlama, hareket etme ve isteme yetilerine sahiptirler. Ancak bu yetiler içgüdüseldir. Bir iradenin ürünü değildir. İnsani ruhun bir faaliyeti olan iradi hareket yalnızca insanlarda bulunur. İnsanın hareketleri hem isteğin hem de aklın devreye girdiği bir süreçten geçer ve bu hareketler içgüdüsel değil, bir iradenin ürünüdür (Nordenfalk, 1985; Kaya, 2014).

İnsan ruhunu belirtilen şekilde hayvanlardan farklılaştıran Aristoteles, benzer bir düşünceyi duyular konusunda da geliştirmiştir. Ona göre ruhun işlevlerinden biri de duyumdur. Duyum için hem özel hem de ortak duyuya ihtiyaç vardır. Özel duyular görme, işitme, koklama, tat alma ve dokunmadır. Her özel duyu da ayrı ayrı renk, ses, koku, lezzet ve dokuyu konu edinir. Aristoteles beş tane özel duyuya ek olarak 'ortak duyu'yu ekler. Ortak duyu, birden çok duyu organının ve duyumun ortak konusudur. Ortak duyusallar ise hareket, dinginlik, sayı, biçim, büyüklük ve zamandır. Ortak duyu, duyuların algıladıklarını zihinde tesis eder ve duyana duyumun bilincini sağlar. Örneğin ortak duyu sayesinde dil hem tat alır hem de yediğinin tadı konusunda bilince sahip olur (Kaya, 2014).

Aristoteles'in insani ruh, akıl ve ortak duyu üzerine ileri sürdükleri ilerleyen yıllarda farklı coğrafyalarda ortaya çıkan Semavi dinlere de sıçramıştır. Aristoteles'in ileri sürdüklerini çağrıştıran akıl, irade gibi kavramlar insanı diğer hayvanlardan ayırmada kullanılmıştır. Hıristiyan metinlerde duyular genellikle dünyevi hazlara giden geçitler olarak görülmüş ve ahlaki ders vermek amacıyla kullanılmıştır. Buna paralel olarak da Ortaçă̆'da Kilise ve din adamları duyulara oldukça şüpheci bir şekilde yaklaşmışlardır. Duyuların kösnül (bedensel) aşka duyulan arzuyu artırdığını ve bu nedenle de onları kontrol altına almanın gerekliliğini vurgulamışlardır. Onlara göre duyular aklın ve bedenin zayıf noktalarına nüfuz etmekte ve kişiyi günaha sürüklemektedir. Duyular aracılığıyla günahlar, kişinin ruhuna saldırmakta ve onları baştan çıkarmaktadır (Nordenfalk, 1985).

Beş duyu üzerine gerek felsefe gerekse din alanında yaşanan tartışma kendisini edebiyatta ve sanatta da göstermiştir. Özellikle görsel sanatlarda Ortaçă̆'dan itibaren gravürlerde, duvar dokumalarında ve tablolarda beş duyu teması yoğunlukla işlenmiştir. Bu eserlerde yukarıda bahsedilen yazına paralel olarak Aristoteles'in kuramının ve kutsal kitap metinlerin yorumlandığı görülmektedir. Ressamlar ve sanatın patronları, dönemin dini, toplumsal, kültürel ve ekonomik atmosferi sonucunda beş duyu temasını farklı üsluplarla yorumlamıştır. 


\section{YÖNTEM}

Beş duyunun ve tat alma duyusunun alegorik anlatımlarını sergilemeyi amaçlayan bu betimsel çalışmada tarama yöntemi kullanılarak gerekli literatür taranmıştır. Beş duyunun ve özellikle de tat alma duyusunun resim sanatındaki örnekleriyle aydınlatılması, duyuların ve lezzetin toplumsal, kültürel, dini ve ekonomik göstergelerle olan ilişkisine dair değerlendirmeler yapmak ve bu olgular arasında olası ilişkileri ortaya çıkarmak için bu yöntem kullanılmıştır. Bu doğrultuda beş duyu, tat alma duyusu olguları doğrudan aranmış, olgulara dair literatürde yer alan tüm araştırmalar taranmıştır. Beş duyu ve tat alma duyusunun tasvir edildiği görseller de tarandıktan sonra ortaya çıkan tüm kavramlar etraflıca tanımlanmış ve açıklanmıştır.

\section{SANATTA DUYULARIN ALEGORIK ANLATIMI}

Resim sanatında Beş Duyu temalı resimli sunumlar güçlülerin ve zenginlerin sahip olduğu bolluğu göstermek için oldukça elverişli sahnelerdir. Bu sahnelerin ele alınma nedenleri farklılık gösterir. Kimi resimlerde ahlaki veya dini bir mesaj verilmesi amacı güdülürken, kimi tablolarda da alegorik bir anlatımla iktidar sahiplerinin zenginliği ve gücü gözler önüne serilmektedir. Kimi tablolarda ise her iki amaç birden gözlemlenir.

Resim sanatında beş duyunun temsil edilmesi üç farklı grupta yapılabilir. Birinci gruptaki resimlerde duyular objeler ve kişiler aracıllğıyla doğrudan ve çok belirgin tasvir edilmektedir. Bu gruptaki resimlerde duyuların tamamı ya tek bir tabloda toplanır ya da her bir duyunun ayrı tablolarda bir seri şeklinde temsil edildiği görülmektedir. Bu grupta yer alan resimlerde her bir figür ya da objenin bir duyuya karşlık gelmesine dikkat edilir (örn. Resim 1). İkinci gruptaki resimlerde ise beş duyu teması genellikle gündelik hayatı temsil eden bir sahnenin içine gizlenmiştir. Bu resimlerde tasvir edilen beş duyuyu fark edebilmek için resimde tasvir edilen sıradan insanların eğlenceli dünyasına alegorik bir gözle bakmak gerekir (örn. Resim 9). Beş duyunun resim sanatındaki temsillerine dair bir diğer grup ise natürmort (ölüdoğa) türüdür. Bu gruptaki resimlerde beş duyu ne ilk gruptaki gibi çok net bir şekilde tasvir edilmiş ne de ikinci gruptaki gibi ilk bakışta tamamen ilgisiz gibi görünen bir sahnenin içine gizlenmiştir. Ölüdoğa resim örneklerinde beş duyunun temsili bu iki grubun arasında gidip gelir. Bu natürmortlarda nesneler duyuları temsil etmekte kullanılır. Resimlerde sıkça kullanılan kurukafalar, boş bırakılmış bardaklar, solmakta olan çiçekler, yanmış mumlar ya da kopmuş enstrüman telleri aracılığıyla hem beş duyu temsil edilir hem de varoluşun geçiciliği hatırlatılır (Erdoğdu, 2018) (örn. Resim 5).

\section{Beş Duyunun Berrak (Açık) Temsilleri}

Tüm duyuların çok açık ve berrak bir şekilde tasvir edilmesinin ilk örneklerinden biri Adriaen Collaert tarafından 16.yy sonlarında ortaya konmuştur. Collaert'in gravüründe (Resim 1) açık havadaki bir masanın etrafında eğlenen çıplak beş kadın ve bir erkek figür bulunur. Beş kadından her biri beş duyuyu şu şekilde temsil eder: en solda bir elinde meşale diğer elinde ayna tutan figür görme duyusunu; onun yanında bir elinde meyve sepeti diğer elinde şarap kadehi tutan figür ile üstteki dalda meyve yiyen maymun tat alma duyusunu, bir elinde bir buket çiçek diğer elinde defne yapraklarından yapılmış bir çelenk tutan figür koklama duyusunu, en sağda erkek figürün sarıldığı kadın figür dokunma duyusunu ve en önde arkası dönük lavta çalan figür ise işitme duyusunu yansitmaktadır (Kermode, 1961-62; Kitisakan, 2018). 


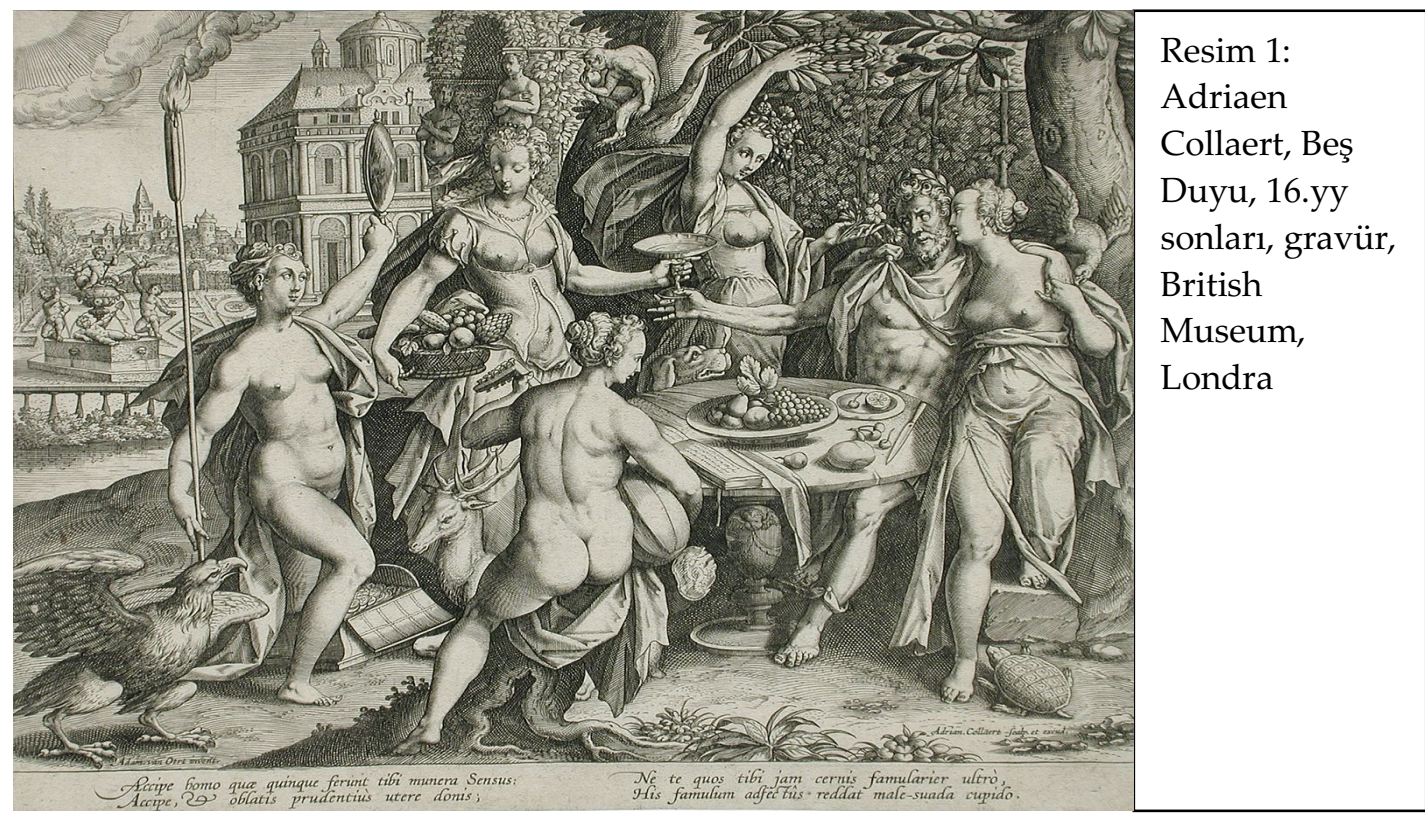

Jan van Bijlert'in alttaki resminde (Resim 2), beş duyu çok berrak bir biçimde betimlenmiştir. Solda elinde ayna tutan kadın figür görme duyusunu, onun arkasında gül koklayan erkek figür koklama duyusunu, ortada lavta çalan figür işitme duyusunu, onun solunda kendini çimdikleyen figür dokunma duyusunu ve son olarak en sağda sıktığı üzümün suyunu içen figür de tat alma duyusunu sembolize etmektedir.

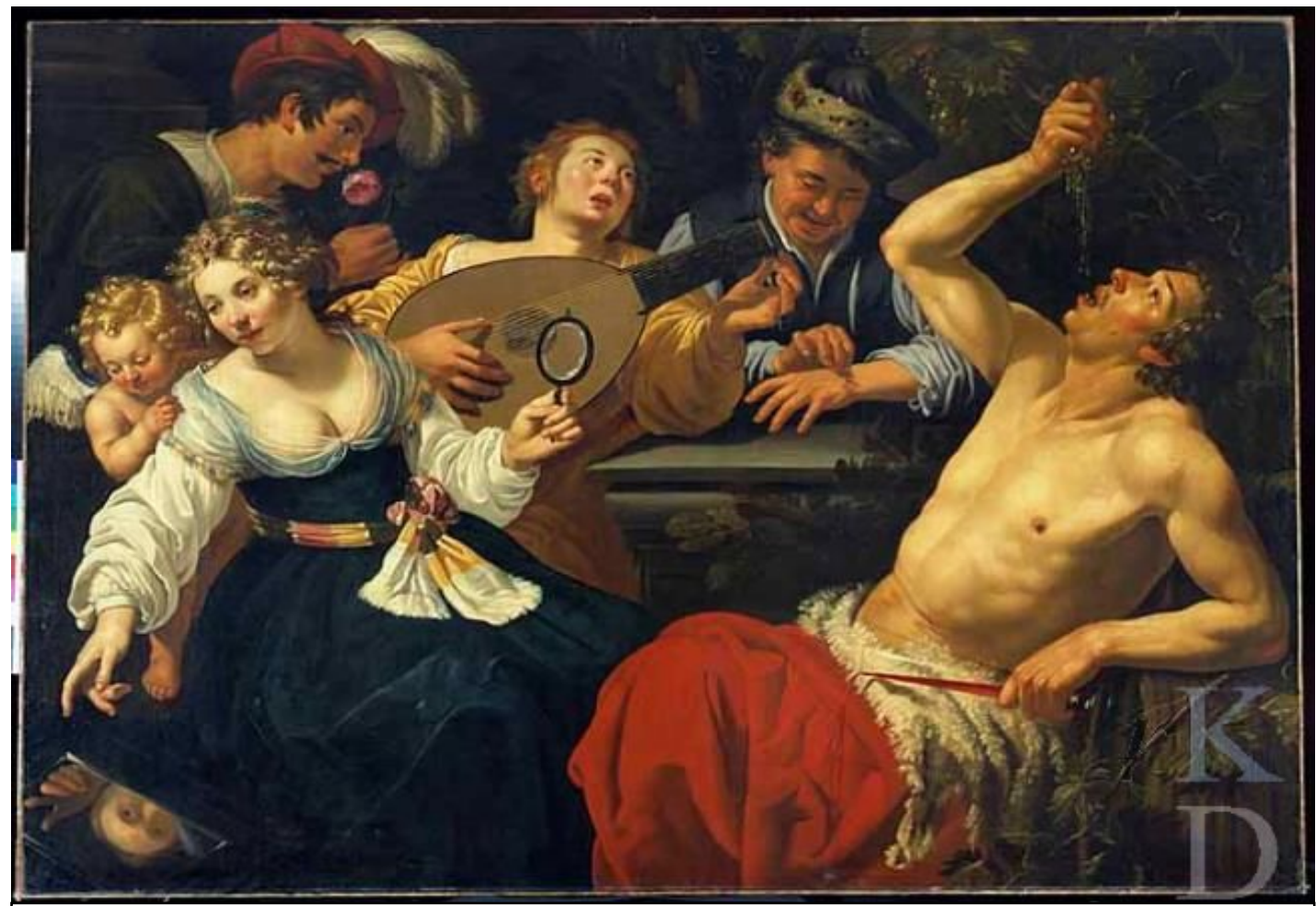

Resim 2: Jan van Bijlert, Beş Duyu (The Five Senses), 1625-30, The Davis Museum, Wellesley. 
Beş duyunun en net biçimde temsil edildiği resim sanatı örneklerinden biri de şüphesiz ki seri halinde yapılan resimlerdir. Bu üsluba ait en eski örneklerden biri de 1.500 yılı civarında dokunmuş, yün ve ipek iplikten imal edilmiş altı dokumadan (goblen) oluşan 'Kadın ve Tek Boynuzlu At (The Lady and The Unicorn)' adlı Fransız seridir. Bu dokumaların her biri alegorik bir şekilde beş duyuyu temsil eder: tat alma, işitme, görme, koku ve dokunma. Altıncı dokumanın anlamı ise belirsizdir. Üzerinde "À mon seul désir (Benim tek arzum)" yazar ve anlamına dair farklı yorumlar bulunur. Bunlar arasında diğer beş parçayı yani diğer beş duyuyu terk etmek, kalbe, aşka ya da özgür iradeye ulaşmak, Aristoteles' in ortaya koyduğu altıncı duyu olan 'ortak duyu' ya da 'insani ruh' kavramına yönelmek gibi yorumlar bulunmaktadır (Nordenfalk, 1985; Toker, 2017).

'Kadın ve Tek Boynuzlu At'tan sonraki yüzyıllarda beş duyu alegorik olarak bir seri halinde tasvir edilmeye devam etti (örn. Sebastian Brant adlı Alman Hümanist yazarın 'Aptallar Gemisi (Das Narren-Schyff)' adlı şiirinden esinlenerek 'Adem ile Havva'nın Gemisi, Görme Gemisi, İşitme Gemisi, Koklama Gemisi, Tat Alma (Lezzet) Gemisi ve Koku Gemisi' isimli altı tane gravür çizen Fransız ressam Jodocus Badius Ascensius'un serisi- Resim 10) (Nordenfalk,1985). Bu yapıttan sonra tüm duyuların ayrı ayrı bir seri biçiminde tasvir edildiği belki de en ünlü tablo dizisi ‘Beş Duyunun Alegorisi (Allegory of the Five Senses)'dir (Resim 4,5,6,7,12). Beş eserden oluşan tablo serisi İspanyol Hollanda'ya (Katolik İspanya yönetimindeki Hollanda toprakları) valilik yapan Arşidük Albert ve Isabella çifti için, Flaman ressam yaşlı Jan Brueghel (1568-1625) ile onun yakın arkadaşı ve aynı zamanda Arşidükün saray ressamlığını yapan Peter Paul Rubens (1577-1640) tarafından 16171618 yılları arasında resmedilmiştir. Tablolardaki kompleks ikonografi ile, sarayı ziyaret eden elit davetlilere bazı mesajların verilmesi amaçlanmıştır. Tablolarda kullanılan görsel dil, 17.yy'ın erken dönemlerinde Antwerp'in sahip olduğu estetik mirası yansıtmaktadır. Bu dönemde Albert ve Isabella, 30 Yıl Savaşları'ndan sonra fakirleşmiş Alçak Ülkeler'e getirdikleri barış ve zenginlikle çevrelerini etkilemeye çalışmaktadırlar (McFadden, 2014).

Yaklaşık olarak aynı ebatlardaki beş tablonun her birinde tasvir edilen duyuyu çağrıştıran objeler yığını bulunmaktadır. 'Görmenin Alegorisi'nde (Resim 4) görme duyusunu temsil eden kadın figür İsa'nın gözleri görmeyen birisinin gözlerini açtığı mucizesinin tasvir edildiği bir tabloyu seyre dalmıştır. Tablo, ancak görme duyusu aracılığıyla algılanabilen pek çok sanat objesinin, büstün, tablonun, bilimsel aletin dolup taştı̆̆ adeta görsel bir şölendir. 'İşitmenin Alegorisi'nde (Resim 5) kadın figür, kulağın algılayabileceği sesleri çıkartan müzik enstrümanları, saatler ve ötücü kuşlarla dolu bir odada lavta çalmaktadır. 'Koklamanın Alegorisi' nde (Resim 6) kadın figür kokulu çiçeklerle dolu bir bahçededir. Kadının çevresinde üstün koku alma yeteneği olan köpek, kötü kokular saçan bazı hayvanlar (örn. kokarca) ve parfüm şişeleri bulunurken, tablonun sol bölümünde tasvir edilen parfüm damıtma işi ve mekanı koklama duyusunu sembolize etmektedir. 'Dokunmanın Alegorisi'nde (Resim 7) kadın figür kanatlı küçük bir meleği kucaklamakta ve öpmektedir. Tabloda dokunma duyusu sayesinde hissedilebilen ve/ya işlevsellik kazanan peç çok nesne bulunmaktadır: savaş zırhları, miğferler, kalkanlar, oklar, mızraklar, medikal el aletleri, çalı süpürgeleri, yere saçılmış kâğıtlar, yerde yanan ateş, acı veren böcekler vb. Sol arka planda demir döven işçiler, bir eşeği hareket ettirmeye çalışan insanlar, tarla hasadı yapan çiftçiler, kendisinden daha küçük bir kuşu ağzında taşıyan kuş imgeleri dokunma ve hissetme duyusunu temsil etmektedir. 'Tat Almanın Alegorisi'nde (Resim 12) kadın figür, pek çok yiyecekle donatılmış bir masada istiridye yemekte ve bir satir kadehine şarap doldurmaktadır. 'Tat Almanın Alegorisi' ayrıntılı olarak ilerleyen bölümlerde (Bölüm 5) incelenmektedir. 


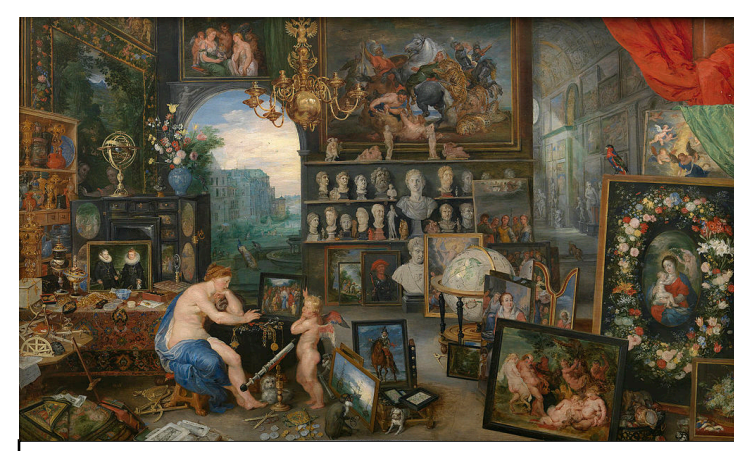

Resim 4: Yaşlı Jan Brueghel ve Peter Paul Rubens, Görme'nin Alegorisi, 1617, Prado, Madrid

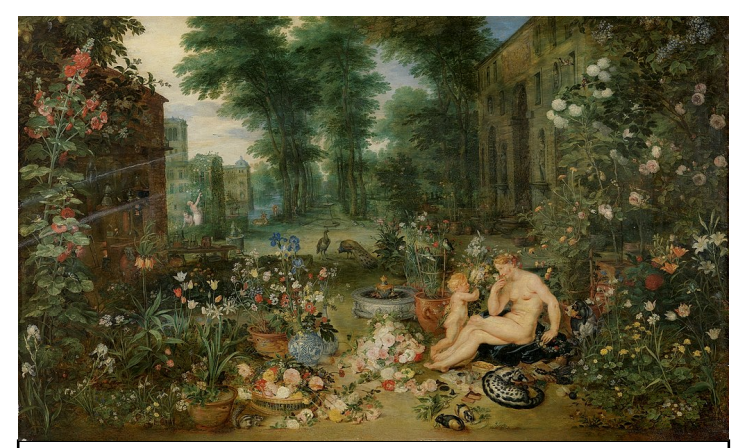

Resim 6: Yaşlı Jan Brueghel ve Peter Paul Rubens, Koklama'nın Alegorisi, 1617-18, Prado, Madrid
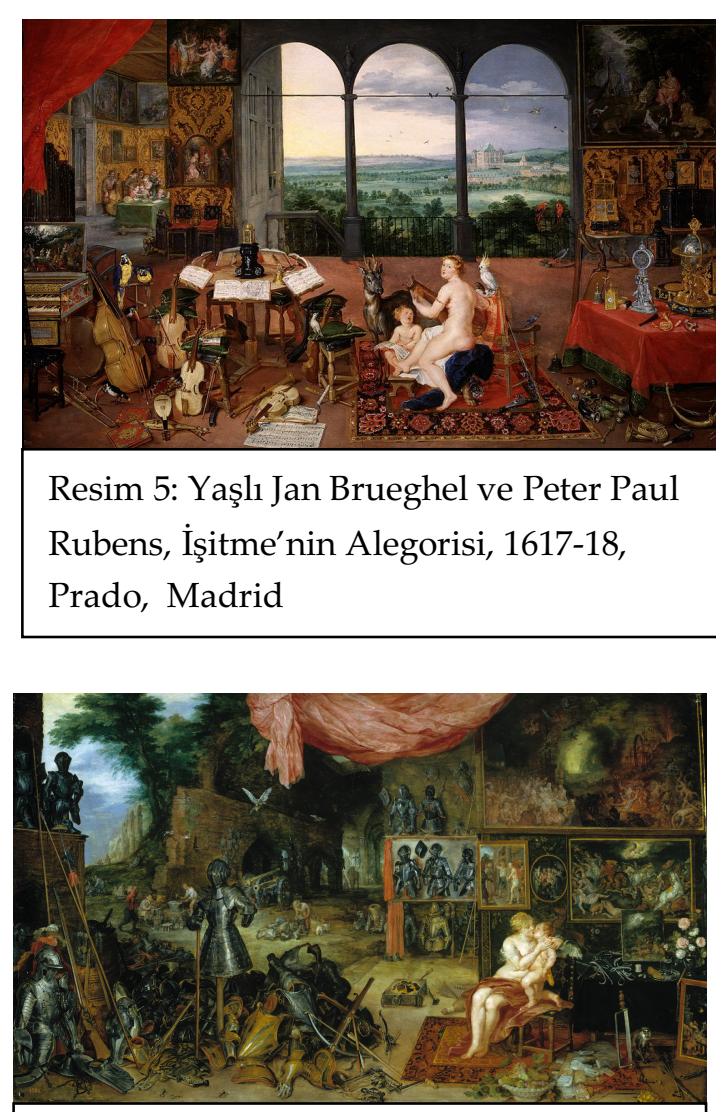

Resim 7: Yaşli Jan Brueghel ve Peter Paul Rubens, Dokunma'nın Alegorisi, 1617-18, Prado, Madrid

\section{Beş Duyunun Belirsiz (Örtük) Temsilleri}

Beş duyunun tamamının tek bir tabloda belirsiz bir şekilde tasvir edildiği ikinci gruptaki sahneler genellikle 'Neşeli Aile (Merry Family, Merry Company)' temalarının işlendiği janr (tür) sanatı örneklerinde görülür (Kitisakan, 2018). Tür sanatına dair örnekler günümüzde Belçika, Lüksemburg ve Hollanda topraklarını kapsayan Alçak Ülkeler'de 16. ve 17. yüzyıllarda oldukça yaygın görülmeye başlanmıştır. Tür resim sanatı Alçak Ülkeler'de Katolik inancının zayıflaması ve Hollanda'nın deniz ticareti sayesinde zenginleşen burjuva sınıfının artık din dışı resimler sipariş etmeye başlamasıyla ortaya çıkmıştır. Geleneksel din odaklı sanattan kopmanın yaşandığı bu dönemde ressamlar gündelik hayattan sahneler betimlemeye başlamıştır. Bu yeni sanat anlayışında farklı toplumsal sınıflar, özellikle de alt tabakalar genellikle evlerde, tavernalarda, sokaklarda, festivallerde resmedilmiştir. Halkın eğlenceli dünyasının yanı sora fakirliği ve sefaleti de bu resimlerde örtük bir mizah anlayışıyla betimlenmiştir (Akdeniz Ay, 2017; Çeler, 2012). 
İkinci gruptaki resimlerde tasvir edilen beş duyuyu fark edebilmek için dikkatli ve eğitimli gözler gerekmektedir. Örneğin Jan Steen'in 'Lüksten Kaçının (Beware of Luxury)' adlı tablosunda (Resim 8) dört yetişkin, bir ergen, üç çocuk, bir bebek, bir domuz ve bir köpekten oluşan sahnede ilk etapta dikkati çeken dağınıklığın ve kargaşanın içinde beş duyu temasını tespit etmek görece daha güçtür. Tablodaki görme duyusu sırtında ördek bulunan siyahlar içindeki bir erkek figürün yanındaki kadına elindeki kitaptan bir şeyler okumasıyla, koklama duyusu sağ planda yere atılmış çiçekleri koklayan bir domuzla, işitme duyusu keman çalan bir ergenle temsil edilmiştir. Sol alt köşede mama sandalyesinde oturan küçük bebeğin elinde tuttuğu kaşık ve kolye dokunma duyusunu sembolize ederken, ön planda elinde bir şarap testisi ve kadehi tutan kadın ile masanın üzerindeki turtayı yiyen köpek tat alma duyusuna gönderme yapmaktadır (Kitisakan, 2018).

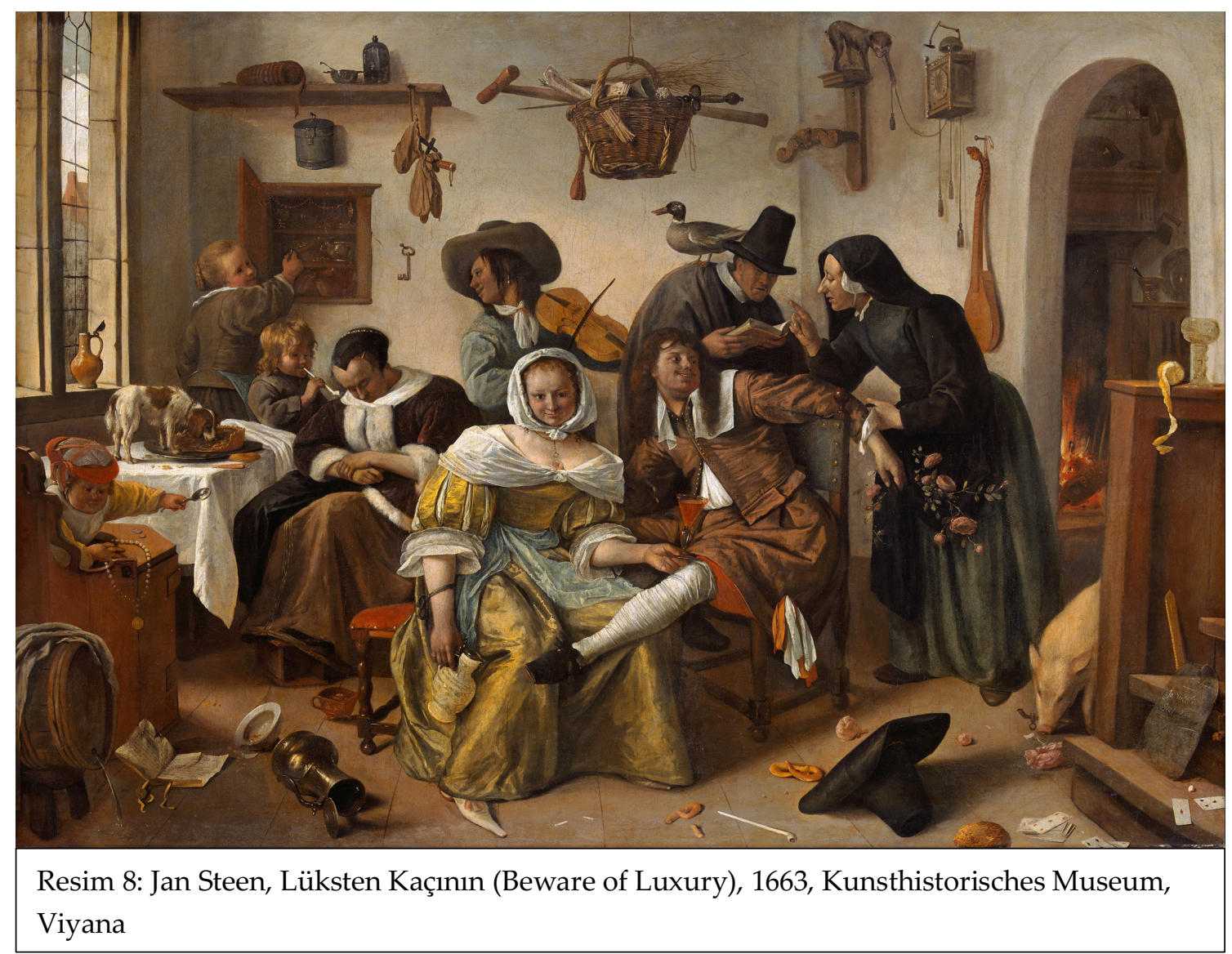

Jan Steen ve pek çok Flemenk ressam tarafından sıklıkla ortaya konan tür sanatı örneklerinin çoğunda saklı bir ahlak dersi ve sembolik bir mesaj bulunur. Günlük yaşam sahnelerinde ön planda betimlenen eğlence, haz, arzu, alay ve mutluluk dolu atmosfer bir yandan alt sinffların nasıl yaşadığını söyler, diğer yandan da nasıl yaşamaması gerektiğini. Gözün gördüğü aslında doğru bir yaşantı değildir. Resimlerdeki karakterler Tanrı'yı hiçe sayıp günlük hayatın neşesine kapılmışlardır. Ve bunun da bedelini fakir kalarak ödemektedirler. Böylesine bir alegorik anlatımla ressamlar görünen sahnedeki ahlaki çözülmeye bir eleştiri yapmakta ve sıradan insanları nasıl yaşamaları gerektiği konusunda güçlü bir şekilde uyarmaktadır (Akdeniz, 2018; Çeler, 2012). 


\section{Berraklık ve Bulanıklık Arasındaki Beş Duyu Temsilleri}

Bu grupta ölüdoğa ve vanitas türündeki resim sanatı örnekleri bulunur. Ölüdoğa resimleri zengin bir şekilde donatılmış sofraları ya da incelikle düzenlenmiş çiçekleri sergileyen tablolardır. Ölüdoğa resim sanatı örneklerinde beş duyu teması bundan önce bahsedilen eserlere benzeyen simgesel referanslar taşımaktadır. Bu resimler sanatın zengin patronlarının rafine zevklerini sergilemekle birlikte, bu dünyanın gelip geçiciliğini simgeleyen ilahi kodlar taşımaktadır (Çeler, 2012). Özellikle 17. yüzyılda Hollanda'da bir daha hiç ulaşamayacağı bir popülerliğe kavuşan ölüdoğa resimleri, sık sık zenginlerin dünyasından seçkin nesneler betimlemektedir: parlak pirinç vazolar, kristal bardaklar, parıldayan inciler, egzotik midyeler ya da kıymetli porselenler. Geçici güzellikleri ölümsüzleştiren bu tür resimlerde doğanın ve gündelik nesnelerin tüm güzelliği kabul edilir, bunların zevkine varılır ancak asla fazla abartılmazdı. Gerçekmiş gibi görünen nesneler aracılığıyla, insan nesnenin hayatta bir yanılsamadan ibaret olduğunu her zaman aklında tutabiliyordu (Krausse, 2005:44).

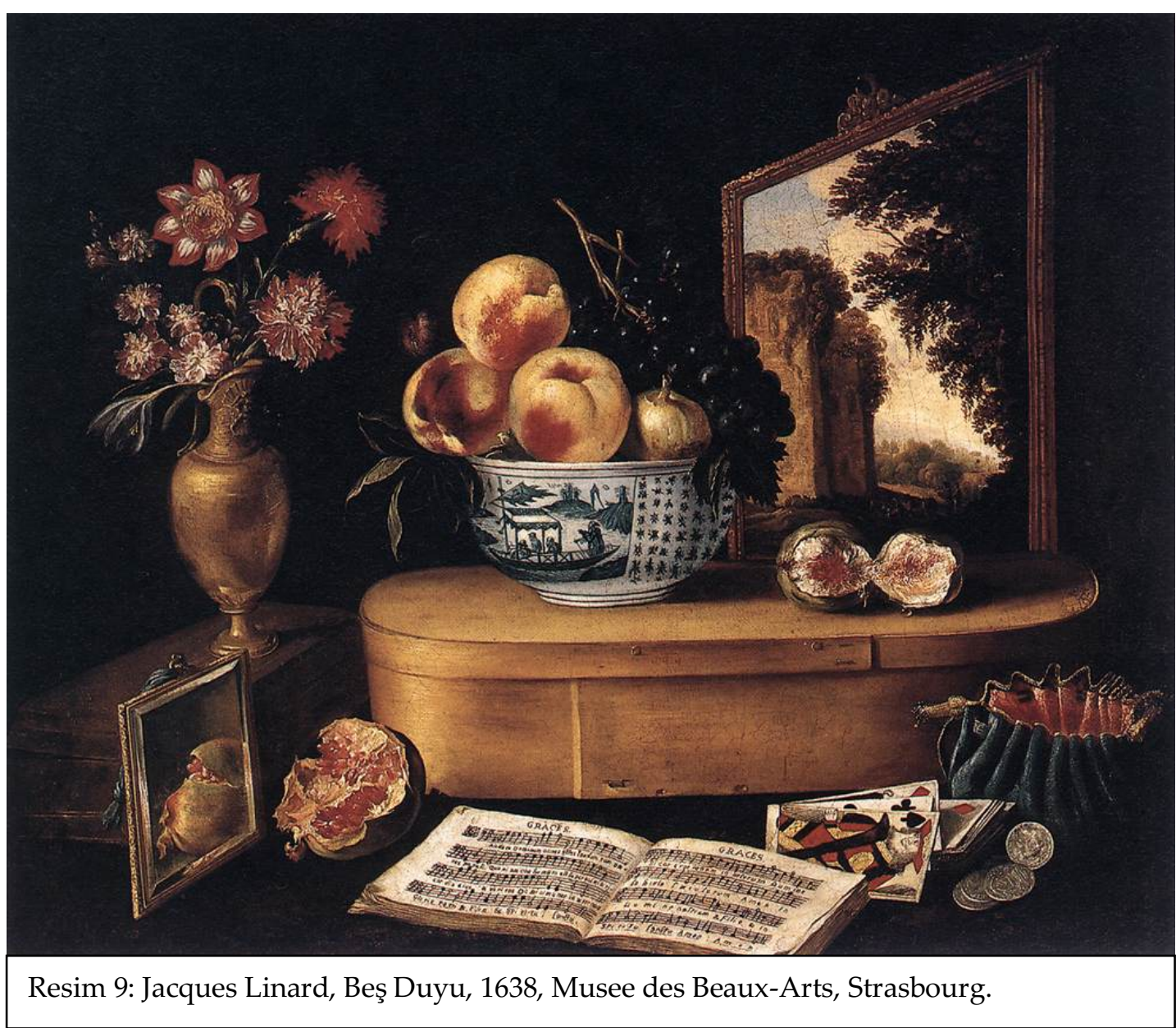

Linard'ın beş duyuyu tasvir eden ölüdoğa resminde (Resim 9) derin bir Çin porselenin içinden neredeyse taşan şeftaliler, büyük bir salkım üzüm, yanında ortadan ikiye yarılmış olgun bir incir ve yarılmış nar tat alma duyusunu yansıtmaktadır. Bu imgelerle temsil edilen tat alma duyusu bedensel hazlara düşkünlüğe gönderme yapmaktadır. Ön plandaki açık nota defteri işitme duyusunu simgelemektedir. Bu defterde bir Şükran Günü ilahisi olan 'Laudate Dominum'un notaları bulunur. 'Tanrı'ya şükürler olsun' şeklinde Türkçe'ye çevrilen bu ilahi söylem, maddi ve 
manevi dünya arasında yapılan alegorinin bir parçasıdır. Aynadaki nar görüntüsü görme duyusunu sembolize etmektedir. Hıristiyan ikonografisinde dirilişin, sonsuz hayatın ve kilisenin sembolü olarak görülen nar imgesiyle, dünyevi gerçekliğin ötesindeki ebediyete gönderme yapılmaktadır (Akdeniz, 2018). Resimdeki oyun kartları, madeni paralar ve ağzı açık para kesesi dokunma duyusunun simgeleridir. Resim sanatında genellikle kötü alışkanlıkların, tembelliğin ve çürümüşlügün simgesi olan bu nesneler bedensel hazlara düşkünlüğün ve fani eğlencelerin tehlikesine işaret etmektedir (Carr-Gomm, 2014). Resimde fani ve daimi dünyaya dikkat çeken bir diğer alegorik sunum ise solmakta olan çiçekler ve kurumakta olan yapraklar ve olgunluğunun doruğuna ulaşmış meyvelerle yapılmıştır. İzleyiciye zamanın akışını ve nesnelerin cazibesini kısa sürede kaybedebileceğini anımsatan bu görüntüler, nesneler karşısında düşülen yanılsamalara ve yaşamın kaçınılmaz sonuna işaret etmektedir.

\section{SANATTA TAT ALMA DUYUSU}

Tat alma duyusu, yeme eylemi ve lezzet üzerine ortaya konan resim sanatı örneklerinde zengin bir alegorik anlatım görülür. Doğanın insana sunduğu pek çok lezzet bu duyu aracıllğıyla bedene transfer edilmektedir. Bu transfer kişiyi beslemek ve doyurmakla beraber lezzetin uyandırdığ tüm hazların da bedene alınması anlamına gelmektedir. Lezzet, bazen yasak meyveyi Havva'ya yediren şeytani bir güdüyü, insanın günahkâr doğmasıyla sonuçlanan bir günahı, medeni insanın hayvani yönlerini ve vahşiliğini, kadınsı şehvetleri, kösnüllüğü sembolize eden bir imge olarak ele alınmıştır. Lezzet üzerinden yapılan bu ikonografik çağrışımlar ve lezzet sembolizmi bu bölümde çeşitli örneklerle ayrıntılandırılmıştır.

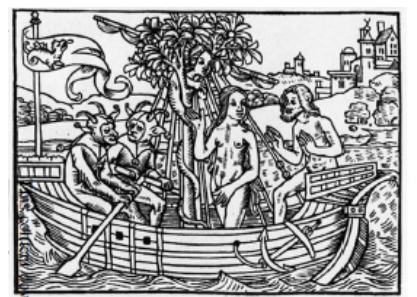

10a. Havva'nın Gemisi

10d. Koklama'nın Gemisi

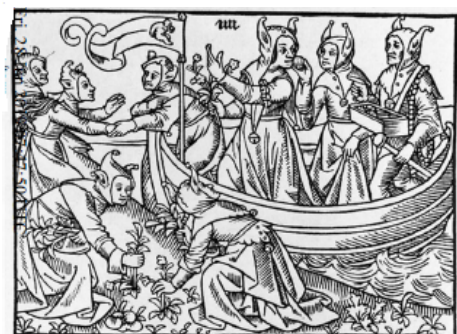

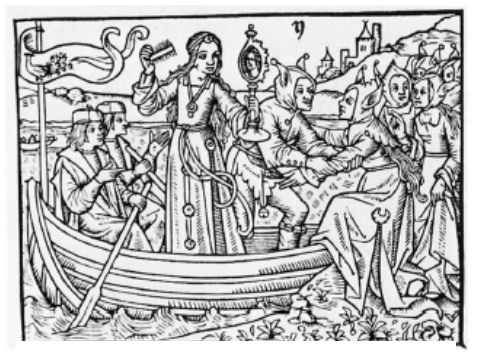

10b. Görme'nin Gemisi

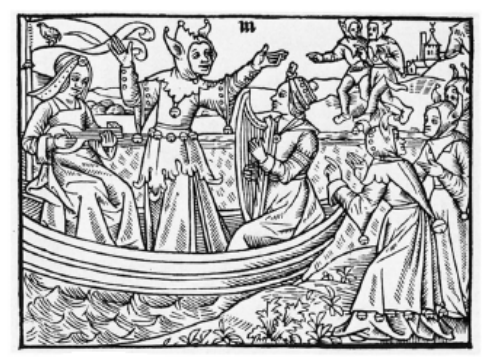

10c. İşitme'nin Gemisi

10f. Dokunma'nın Gemisi

10e. Tat Alma'nın Gemisi
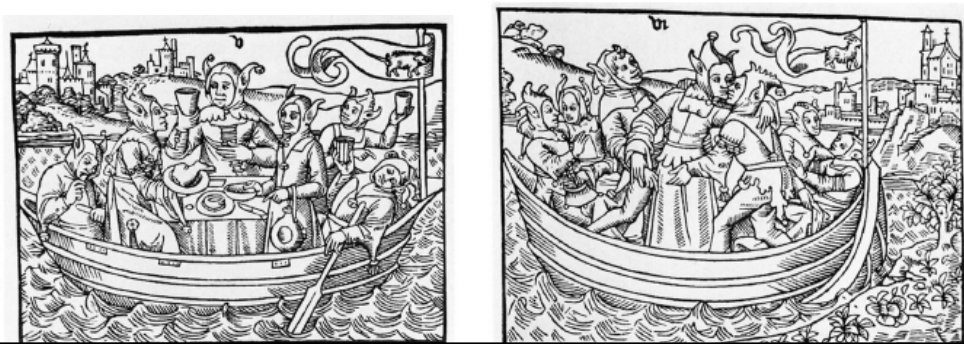

Resim 10: Jocodus Badius Ascensius, Beş Duyu, Stultiferae Naves, Paris, 1500

Badius'un Tat Alma (Lezzet) Gemisi'nde (Resim 10e) gemi yüzen bir tavernaya benzemektedir. Gemide bir sofra kurulmuştur ve 'Lezzet' o masada oturmaktadır. Lezzet, dar kiyafetler giyen tombul bir kadındır. Sağ eliyle kulpsuz bir içki kadehi kaldırmış ve çok fazla içtiğini belli etmek amacıyla diğer elini de göbeğinin üzerine yerleştirmiştir. Soytarı gibi giyinmiş iki kadın figür kendisine hizmet etmektedir. Bunlardan biri Lezzet'e bir domuz budu sunmaktadır. Kürekçi erkek figürler cümbüş yapmaktan görevlerini yapmayı unutmuşlar, içlerinden birisi 
sarhoşluktan dolayı yere yığılmıştır. Geminin sancağında 'Oburluk' günahını sembolize eden domuz resmi bulunmaktadır (Nordenfalk, 1985).

Daha önce bahsedildiği üzere Badius beş duyunun her birini ayrı bir duyu gemisi olarak tasvir etmiş ve bu beşli serinin başına 'Havva'nın Gemisi'ni (Resim 10a) eklemiştir. Bu oldukça dikkat çekici bir husustur çünkü Badius'un beş duyunun girişine yerleştirdiği bu tasviri duyular ile günahkârlık arasında kurulan ilk bağlantılardan biridir. Bilindiği gibi Havva, cennet bahçesinde yılanın sözüne uymuş ve ilk günahı işlemiştir. Kendilerine Tanrı tarafından kesinlikle yememeleri buyurulmuş yasak meyveyi önce kendisi yemiş daha sonra da Adem'e yedirmiştir. Görüldügü gibi ilk günah, tat alma duyusunun Havva'yı ele geçirmesiyle işlenmiştir. Bunun sonucunda cennet bahçesinden kovulmuşlar ve zorlu bir hayata mahkûm olmuşlardır. Tüm kutsal kitaplarda geçen bu meselle birlikte Havva insanın arzularına yenilip büyük bir bedel ödemesinin ikonografik sembolü haline gelmiştir. Aynı zamanda Havva, zayıf karakteri ve arzularına düşkünlüğü ile bir budalalık imgesi haline gelmiştir. Badius, 'Havva'nın Gemisi'nde geminin direğini meyvesinin yenmesi yasaklanan ağaca (Bilgi Ağact- Tree of Knowledge) dönüştürmüş̧ür. Ağacın önünde duran Havva, yılanın kendisine uzattığı yasak meyveyi kabul etmek üzeredir. Dikkatle bakıldığında yılanın da kadın başlı olduğu görülür. Badius'un vurguladığı kadın-günah ilişkisi göz önünde bulundurulduğunda böylesine bir tasvir karşısında şaşırmak yersizdir.

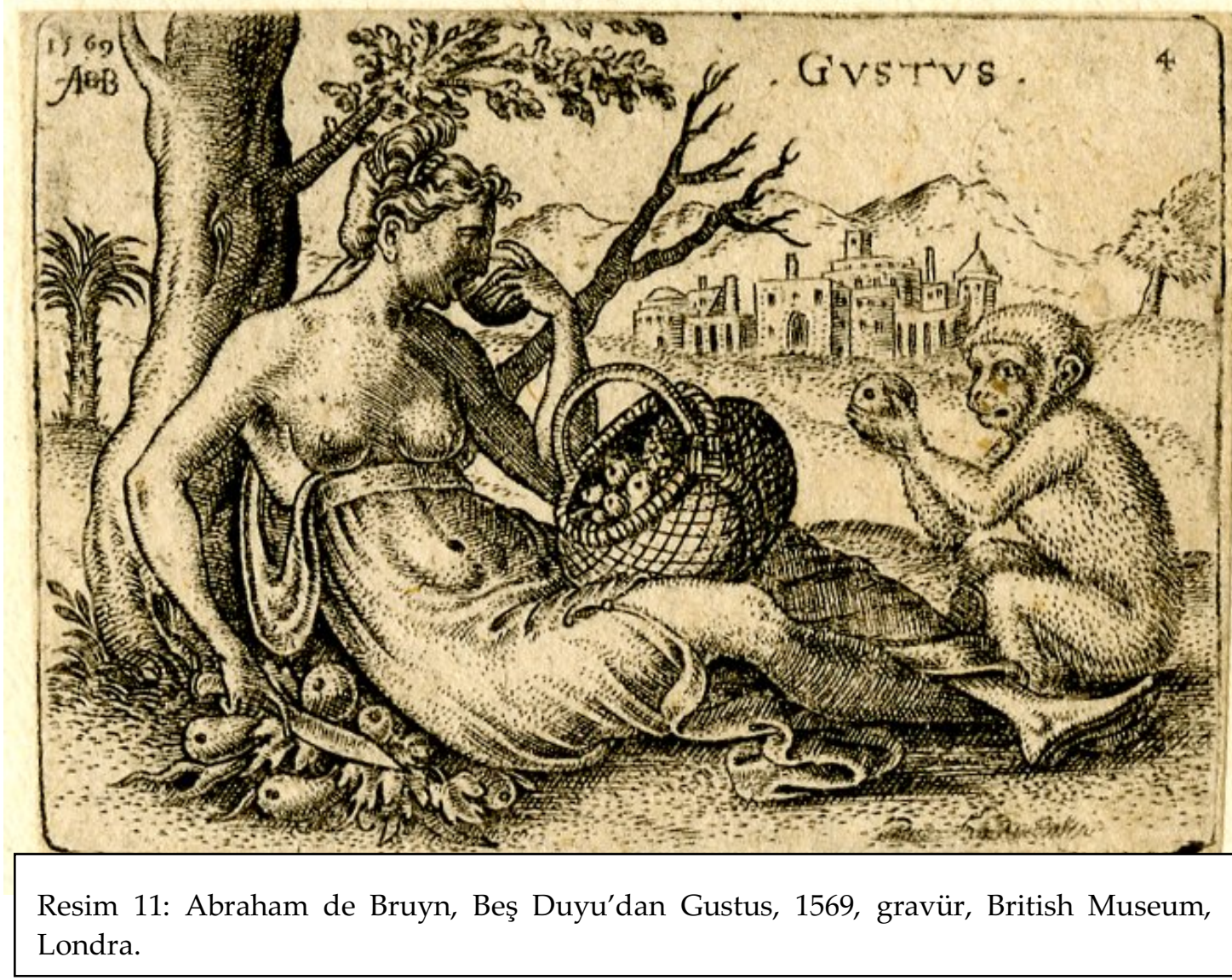

Badius'un duyular ve ilk günah arasında kurduğu bağın benzer bir yorumu Bruyn'un 'Gustus' adlı gravüründe (Resim 11) de görülür. 'Gustus' da yarı çıplak bir kadın figür bir ağacın dibinde yaslanarak oturmakta ve bir meyve yemektedir. Kadının karşısında ona elma sunan bir maymun figür ve arka planda da binaların olduğu bir yerleşke görülmektedir. Hiç kuşku yok ki Havva'yı anımsatan bu kadın figür ile onun ilk günahı işlemesine neden olan tat alma duyusu, gravürde 
ilk günaha dair yapılan kutsal bir sembolizasyonun ürünüdür. Kadının karşısına konan ve 'hayvan insan' olarak kabul edilen maymun ise insanın hayvani ruhunun imgesidir. Daha önce bahsedilen Atistoteles' in 'hayvani ruh' kavramı burada karşımıza bir kere daha çıkmaktadır. Daha önce bahsedildiği üzere, Aristoteles' in insanın hayvanlarla ortak duyusu olan 'tat alma duyusu', sadece insanda bulunan 'insani ruh', 'akıl' ve 'ortak duyu' kavramları sayesinde onu hayvanlardan farklılaştırmaktadır. Platon, tat alabilmek için (aynı zamanda dokunmak ve koklamak için de) fiziksel bir temasın gerçekleşmesi gerektiğinden hareketle, duyular üzerine yaptığı hiyerarşik sınıflandırmada tat alma duyusunu en alt sıraya yerleştirmiştir. Ayrıca onu hayvanlarla ortak paylaştığımız bir duyu olduğu için ilkel ihtiyaçlarımızla ilintili olan hayvansal bir duyu olarak tanımlamıştır. Hayvani duyularımızı anımsatan maymun figürü, resim sanatında benzer örüntülerde ele alınmaktadır. Bu nedenle de insanın medenileşmemiş, vahşi yönlerini sembolize eder (Cohen, 2017; Mcfadden, 2014) İnsanlığın tarihine bizzat evrim geçirerek tanıklık etmiş maymun, evrenin sırlarını bilen bir hayvan insandır. Gravürde arka plandaki yerleşke, medenileşmiş insanın ve toplumun bir ürünü olarak, insan ve maymun arasındaki alegorik anlatımı destekleyen bir imgedir. İnsan maymundan farklılaşabildiği ve ilkel güdülerinden sıyrılabildiği için bir toplum oluşturabilmiştir ve şehirlerde bir arada yaşamaya başlayabilmiştir. Bu bağlamda lezzet, insanın kültürel bir yapı kurabilmesinin karşısında duran, ona bir toplum inşa etmesinde engel olan bir imge olarak sembolize edilmektedir.

Maymun, lezzetin resim sanatındaki alegorik anlatımında farklı bir yorumlamaya daha sahiptir. Maymun lezzetin tadını çıkartan ve insan olmayı başaramamış bir hayvan olarak özellikle Ortaçağ din biliminde şeytan ile özdeşleştirilmiştir. Bu görüşe göre o, insanın değil şeytanın tarafında bir hayvandır. Taklitçi ve düzenbaz karakteri de onun şeytan ile özdeşleştirilmesinde etkili olmuştur. Dolayısıyla maymun, şeytanın ve bedensel hazlara düşkünlüğün kinayeli anlatımı olarak resim sanatında sıklıkla yer almıştır (Mcfadden, 2014).

Badius'un kadın imgesi ile günahkârlık arasında kurduğu ilişkinin bir benzeri Gustus'ta da kurulmuştur. Lezzeti ve dolayısıyla ilk günahı karakterize eden figür bir kadındır. Beş duyuyu ve dolayısıyla da günahkârlığı temsil eden figürlerin kadın olması 1.500'lü yıllardaki ani bir değişimle gerçekleşmiştir. Bundan önceki yıllarda beş duyu tamamıla maskülen (eril) karakterlerle ve/ya hayvanlarla vücut bulmuştur. Latince'de beş duyuya karşllık gelen kelimelerin eril olması dolayısıyla, kavram orijinalinde ve kaçınılmaz bir şekilde maskülinite (erillik) ile ilişkilendirilmiştir. Ancak 1.500'lü yıllardan sonra duyular birdenbire feminen (dişil) bir karaktere bürünmüştür. Bunun ana nedeni ise kutsal metinlerin ve kilisenin kadınlık olgusunu şehvet, duyumculuk ve kösnüllük ile bağdaştırması olarak belirtilir. Badius'un, 'duyular'ı işlenen ilk günahın öznesi konumundaki 'kadın'la ilişkilendirmesi bunu destekler niteliktedir. Ayrıca Latince' de haz ve iffet kavramlarının dişil özellik göstermesi de bu nedenlere eklenebilir. (Nordenfalk, 1985). 


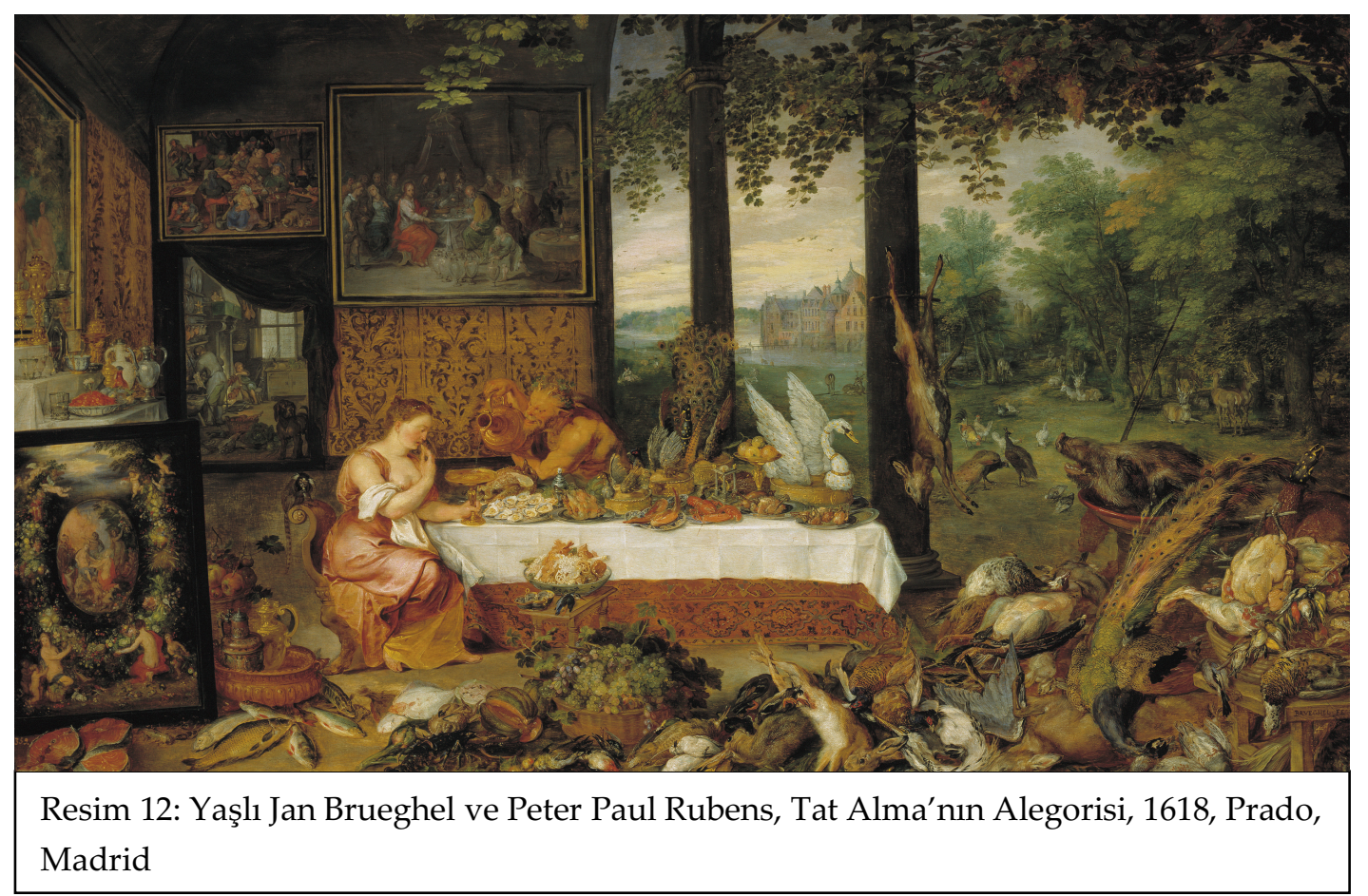

'Lezzetin Alegorisi'nde (Resim 12) 'Lezzet ya da Tat Alma Duyusu', üzerine Türk halısı serilmiş bir masada oturmaktadır. Masanın üzeri dönemin önde gelen zarif tatlarından biri olan kuş turtaları ve diğer ince lezzetlerle ile kaplıdır. Tek parça halinde pişirilmiş av kuşları şatafatlı gümüş servis tabaklarında masada yer almaktadır. Masanın yanında ayrı bir tabakta Avrupa mutfağında yeni yeni yer almaya başlayan ve sadece varlıklı kişilerin bolca tüketebildiği şekerden yapılan tatlı ve şekerleme yığını bulunmaktadır. Lezzet, bir eliyle ağzına istiridye olması kuvvetle muhtemel bir yiyecek götürmekte, diğer eliyle de bir satirin şarap döktüğ̈ bir kylix'i (antik Yunan ve Roma'da şarap içmeye yarayan kulplu ve derinliği az içki kabı) tutmaktadır. Lezzet'in oturduğu sandalyenin sırtında parmak maymun da denilen bir cüce ipek maymunu elindeki yiyeceği kemirmektedir. Daha önce Gustus'ta betimlenen maymun alegorisi (Resim 12) bu tabloda yine benzer bir yorumlama ile karşımıza çıkmaktadır. Lezzet'in Alegorisi, bir ziyafet evinde sahnelenmektedir ve bu ev doğrudan Tervuren Şatosu'nun devasa av sahasına açılmaktadır. Tavandaki sundurmadan asma dalları ve salkım üzümler sarkmakta, şairane kır manzarasında geyikler ve kümes hayvanları serbest gezinmektedir. Yerde yığın halindeki meyveler ve su ürünlerinden oluşan yığın tablonun alt çerçevesini oluşturmaktadır. Aynı şekilde soldaki rafta altın, gümüş ve camdan yapılma içme kapları ile tabaklar ve kaselerden oluşan küme resmin sol çerçevesini oluşturmaktadır.

\section{SONUÇ}

Beş duyu üzerine Antik Çağ'da felsefe alanında ve ilerleyen yüzyıllarda Avrupa'da özellikle din alanında yaşanan tartışmaya edebiyat ve sanat kayıtsız kalamamıştır. Özellikle görsel sanatlarda Ortaçağ'dan itibaren gravürlerde, duvar dokumalarında ve tablolarda beş duyu teması yoğunlukla işlenmiştir. Ortaya konan görsel sanat örneklerinin Aristoteles'in kuramından ve kutsal kitap metinlerinden etkilendiği görülmektedir. Ressamlar ve sanatın patronları, dönemin dini, toplumsal, kültürel ve ekonomik atmosferinden de etkilenerek beş duyuyu temasını farklı şekillerde yorumlamışlardır. 
Diğer duyular gibi 'tat alma duyusu'nun yorumlanması da Antik Çağ'ın düşüncelerinden ve kutsal kitap metinlerinden etkilenmiştir. Beş duyunun sanatta temsillerine paralel bir şekilde 'tat alma duyusu' da insanın çevresini algılamasını sağlayan bir gereç olmaktan öteye taşınmıştır. Yeme eylemi ve tat alma duyusu Aristoteles'in hayvani ruhta ileri sürdüğü gibi kişide arzu duyma ve hareket etme faaliyetlerine sebep olmaktadır. Ancak bu duyu hayvanlarda da bulunmaktadır. İçgüdülerinin kontrolü altında hareket eden hayvanlardan farklı olarak insan, Aristoteles'in akıl ve ortak duyu kavramlarını devreye sokarak bunu kendi iradesi doğrultusunda yapar. Hiristiyan öğretileri ve kutsal kitap meselleri kişinin yemek yeme eylemini ve tat alma duyusunu iradesi doğrultusunda kullanması gerektiğini söyleyerek Aristoteles'in bahsedilen felsefesini çağrıştırır. Hıristiyan inancına göre şayet kişi tat alma duyusunun kendisini ele geçirmesine izin verirse günaha girmiş olacaktır. 'Oburluk', tat alma duyusuna esir olan insanın düştüğü Yedi ölümcül günahtan biridir.

Resim sanatı örneklerinde tat alma duyusunun temsili söz konusu olduğunda 'günahkarlık' karşımıza çıkan ilk olgulardandır. İkonografik açıdan bakıldığında tablolarda 'yasak meyveyi yiyen Havva'nın işlediği ilk günahın yeme eylemi yani tat alma duyusu sonucu gerçekleştiği görülmektedir. İnsanlık tat alma duyusunun kendisini kontrol etmesine izin verdiğinde Tanrı tarafından cezalandırılarak büyük bir bedel ödemek zorunda kalmıştır. Arzularına karşı gelemeyen Havva hem kendisinin hem Adem'in hem de kendilerinden gelen tüm insanlığın cennet bahçesinde yaşamasına engel olmuş, yeryüzünde çilekeş bir hayata mahkum edilmişlerdir. Bu yorumlamalar ışığında bu çalışmada incelen tabloların tat alma duyusunu 'ilk günah' ve 'oburluk günahı'nın ikonu haline getirdiği ve tat alma duyusunun dini bir örüntüde betimlendiği görülmektedir.

Tat alma duyusunun resim sanatındaki temsillerinde görülen dini yapı aynı zamanda ahlaki mesajların verilmesinde aracılık etmiştir. Tablolarda ele alınan 'tat alma duyusu' dünyevi bir zevk olarak tasvir edilmiştir. Ele alınan çalışmalarda bu dünyevi zevk aşırı bolluk ile resmedilmiş ve genellikle bu fani zevklerin karşısına ebedi dünyayı anımsatan dini sahneler konulmuştur. Dünyevi ve uhrevi, maddi ile manevi arasında gidip gelen bu alegorik anlatım sayesinde kişinin yaşarken ilahi dünyayı unutmaması gerektiği uyarısında bulunulmuştur.

Sanatta tat alma duyusunun ilk günahla ilişkilendirilmesi kadın olgusunu tartısmaya açmaktadır. İlk günahın işlenmesine neden olan Havva'nın bir kadın olması ise bu tartışmanın temel dayanağıdır. Tüm kutsal kitaplarda yer alan bu meselde kadın arzularına yenik düşmüştür. Hata yapmaya elverişli zayıf karakteri ve budalalığı yüzünden tüm insanlığı ortak günaha (Hıristiyan inancındaki günahkâr doğma inancı) sokmuştur. İşte bu nedenle kadın şehvetin, kösnüllüğün, iradesizliğin ve günahkârlığın karakterize edildiği imge olarak resim sanatı örneklerinde karşımıza çıkmaktadır. İlk günah sahnelerinde Havva'yı baştan çıkaran yılanın başının kadın şeklinde tasvir edilmesi, çalışmada ele alınan resim sanatı örneklerinde beş duyunun neredeyse her zaman bir kadın figürü olması bunu kanıtlar niteliktedir. Kadın, ilk günahla üstlendiği günahkârlık, şehvet düşkünlüğü ve budalalık ikonunu binyıllar boyunca sırtında bir kambur gibi taşımak zorunda kalmış ve resim sanatını bu kamburuyla en çok meşgul eden imgelerden biri olmuştur. Çıplak, davetkâr, ahlaksız davranışlarda bulunan kadın figürler hem beş duyu ve tat alma duyusu resimlerinde, hem de farklı temalı resimlerde kendilerine kolaylıkla yer bulmuştur.

Yemek yeme dendiğinde akla ilk gelen genellikle bir fiziksel aktivite olmaktadır. Günümüz gastronomi dünyasının önemli bir bölümü farklı lezzetleri keşfetmek ve daha lezzetli yemekler yemek üzerine kuruludur. Sosyal medya, yazılı yayınlar, televizyon programları gibi pazarlama araçlarıyla büyük popülerlik kazanmış bu alanda yapılan bilimsel çalışmalar görece daha azdır. $\mathrm{Bu}$ çalışmada ortaya konan bulgular aracılığıyla yemek yeme olgusuna farklı bir yaklaşım getirilmiş ve nispeten karanlık bırakılan bu alana dikkat çekilmiştir. Yemek yeme olgusu ve beş 
temel duyudan biri olan tat alma duyusuna yalnızca fiziksel perspektiften bakmak yerine, olgu felsefi, sosyal, ilahi, tarihi ve ahlaki bir düzlemde tartışılmıştır. Çalışmanın ele aldığı görsel betimlemelerde yemek yeme eyleminin farklı pek çok bilim dalında yansımaları olduğu gözlenmiştir. Yaptığı görsel çözümlemeler aracılığıyla çalışma, tat alma duyusu üzerine yapılabilecek çalışmalar için yeni bir bakış açısı kazandırmış ve olgunun bilimsel açıdan daha derinlemesine araştırılması için yeni bir anlayış sunmuştur. Çalışmanın ortaya koyduğu bulgular göstermektedir ki, ilerleyen dönemlerde tat alma duyusu üzerine yapılacak çok disiplinli çalışmalar oldukça faydalı olacaktır.

Temel odak noktası olarak gastronomi bilimini önde tutan bu çalışma, amacı ve kapsamı dolayısıyla sosyolojik, felsefi, tarihi, ahlaki vb. tartışmalara daha az yer vermiştir. Bu nedenle gelecekte yapılacak çalışmaların yemek yeme olgusuna ve tat alma duyusuna farklı bilim dalları aracılığıyla derinlemesine kavranması önemlidir. Böylelikle gastronomi üzerine oluşturulan literatür derinleştirilebilir ve artırılabilir.

\section{KAYNAKÇA}

Akdeniz Ay, D. (2017). 17.yy Hollanda Resim Sanatında Yiyecek-İçecek Öğeleri: Portre, Tür ve Ölüdoğa Sanatından Örneklerle, Journal of Tourism and Gastronomy Studies, 5 (1): 76-95.

Carr-Gomm, S. (2014). Sanatın Gizli Dili. (Çeviren, Deadato, L.) İstanbul: İnkılap Kitabevi.

Cohen, S. (2017). Ars simia naturae: The Animal as Mediator and Alter Ego of the Artist in the Renaissance, Explorations in Renaissance culture, 43 (2): 202-231.

Çeler, Z. (2012). 17. Yüzyıl Hollanda Toplumu ve Resim Sanatı Üzerine: Bakış, Üslup ve Yorumlama, Galatasaray Üniversitesi İletişim Dergisi, 16: 65-84.

Erdoğdu Ö. N. (2018). 17. Yüzyıl Hollanda Resim Sanatında Vanitas İmgeleri, Ulakbilge, 6 (21): 143-159.

Harvey, E.D. (2011). The Portal of Touch, American Historical Review, 116 (2): 385-400.

Kaya, M. (2014). Aristoteles'in Ruh Anlayışı, Pamukkale Üniversitesi Sosyal Bilimler Enstitüsü Dergisi, 18: 91-98.

Kermode, F. J. (1961-62). The Banquet of Sense, Bulletin of the John Rylands Library, 44: 68-99.

Kitisakon, K. (2018). The Five Senses in Genre Paintings of the Dutch Golden Age, Journal of Urban Culture Research, 16: 124-139.

Krausse, A.-C. (2005). Rönesanstan Günümüze Resim Sanatınn Öyküsü. (Çeviren, Zaptcığlu, D.) Almanya: Literatür Yayıncılık.

McFadden, E. (2014). Food, Alchemy, and Transportation in Jan Brueghel's The Allegory of Taste, The Journal of Graduate Research in Art History, 30: 35-56.

Magee, J. (2000). Sense Organs and the Activity of Sensation in Aristotle, Phronesis, 45 (4): 306330.

Nordenfalk, C. (1985). The Five Senses in Late Medieval and Renaissance Art, Journal of the Warburg and Courtauld Institutes, 48: 1-22.

Toker, G. (2017). Ortaçağ Halılarında Üretim, Desen Analizi Işığında Kadın ve Tek Boynuzlu At Duvar Halıları, International Journal of Interdisciplinary and Intercultural Art, 2 (2): 55-72. 